ECOLOGICA, Vol. 28, No 101 (2021), 72-81

https://doi.org/10.18485/ecologica.2021.28.101.12

Pregledni rad

UDC:796:[616.98:578.834

\title{
Uticaj Covid-19 na budućnost sporta: održivost i obnova
}

\section{The impact of Covid-19 on the future of sport: sustainability and recovery}

\author{
Violeta Šiljak ${ }^{1}$, Nevenka Zrnzević ${ }^{2}$, Rade Stefanović ${ }^{3}$, \\ Aleksandra Perović ${ }^{4}$, Jovan Veselinović ${ }^{4}$, Dejan Đurović 6 \\ ${ }^{1}$ Evropski centar za mir i razvoj Univerziteta za mir UN, Beograd, Srbija \\ ${ }^{1}$ European Center for Peace and Development, UN University for Peace, Belgrade, Serbia \\ 2Učiteljski fakultet Leposavić, Univerzitet u Prištini, Srbija \\ ${ }^{2}$ Faculty of Teacher Education Leposavić, University of Priština, Serbia \\ ${ }^{3}$ Fakultet sporta i fizičkog vaspitanja Leposavić, Univerzitet u Prištini, Srbija \\ ${ }^{3}$ Faculty of Sports and Physical Education Leposavić, University of Priština, Serbia \\ ${ }^{4,5,6}$ Alfa BK Univerzitet, Fakultet za menadžment u sportu, Beograd, Srbija \\ ${ }^{4,5,6}$ Alfa BK University, Faculty of Sports Management, Belgrade, Serbia
}

Rad primljen: 17.01.2021, Rad prihvaćen: 27.02.2021.

Sažetak: Svedoci smo vremena kada pandemija COVID-19 svojim prisustvom utiče na svakodnevni život pojedinca, time i na sport kao aktivnost ili delatnost kojom se ljudi bave. Međutim, iako su se brojni autori bavili problematikom COVID-19 sa aspekta sporta, imajući u vidu činjenicu da je sport kompleksan fenomen, ostavljeno je dosta prostora za dalja istraživanja o njihovoj povezanosti, odnosno uticaju COVID-19 na sport. U ovom istraživanju eksplorativnog karaktera, s obzirom da se odvija u uslovima aktuelne pandemije, u realnom vremenu, primenjena je deskriptivna, pretežno kvalitativna i kritička analiza sadržaja javno dostupnih, zvaničnih i objavljenih podataka i naučnih radova, kojima se na jasan način mogao ostvariti formulisani cilj istraživanja. Aktuelnost teme je neupitna i diktira je stvarnost u kojoj živimo. Predmet ovog istraživanja se upravo odnosi na uticaj COVID-19 na budućnost sporta, njegovu održivost razvoja, tj. oporavka. Cilj istraživanja predstavlja sveobuhvatno sagledavanje i razumevanje problema i dimenzija aktuelne pandemije COVID-19 u funkciji održivog razvoja sporta. Polazeći od predmeta i cilja istraživanja definisana su istraživačka pitanja, pri čemu se došlo do rezultata istraživanja koji ukazuju da je perspektiva školskog i vrhunskog sporta i uz napore resornih udruženja na zabrinjavajućem nivou, dok je segment rekreativnog sporta moguće održati na istom nivou uz preorijentaciju i usmerenost na bavljenje aktivnostima na otvorenom prostoru. Za sada nije uočeno da su strategije razvoja sporta redefinisane. Donešen je određen broj uredbi, preporuka i sl. što navodi da se u ovom momentu još uvek razmišlja o COVID-19, kao prolaznom problemu, gde bi se nakon završetka pandemije vratilo već postojećim strategijama razvoja i održivosti.

Ključne reči: sport, pandemija COVID-19, budućnost sporta, održivost, razvojne strategije, rekreativni sport, vrhunski sport, školski sport.

\footnotetext{
10rcid.org/0000-0002-3553-8906, e-mail: vikica.siljak@gmail.com 2orcid.org/0000-0001-6053-9954, e-mail:nevenka.zrnzevic@gmail.com

${ }^{3}$ orcid.org/0000-0001-6650-7638, e-mail: rade.stefanovic@pr.ac.rs

${ }^{4}$ orcid.org/0000-0001-5528-3536,e-mail: aleksandra.perovic@alfa.edu.rs

${ }^{5}$ orcid.org/0000-0001-7725-8358,e-mail: jovan.veselinovic@alfa.edu.rs

6orcid.org/0000-0001-9846-2841, e-mail: valu@t-com.me
} 
Abstract: We are witnessing a time when the COVID-19 pandemic with its presence affects the daily life of an individual, and thus sports as an activity that people are engaged in. However, although many authors have dealt with the issue of COVID-19 from the aspect of sports, having in mind the fact that sport is a complex phenomenon, a lot of space is left for further research on their connection, ie the impact of COVID-19 on sport. In this exploratory research, given that it takes place in the current pandemic, in real time, a descriptive, mostly qualitative and critical analysis of the content of publicly available, official and published data and scientific papers was applied, which could clearly achieve the formulated goal of research. The topic is unquestionable and is dictated by the reality in which we live. The subject of this research relates to the impact of COVID-19 on the future of sport, its sustainable development, ie. recovery. The aim of the research is a comprehensive understanding of the problems and dimensions of the current pandemic COVID-19 in the function of sustainable development of sports. Starting from the subject and goal of the research, research questions were defined, and the results of the research indicate that the perspective of school and top sports is at a worrying level with the efforts of line associations, while the segment of recreational sports can be maintained at the same level with reorientation and focus to engage in outdoor activities. So far, it has not been noticed that sports development strategies have been redefined. A number of decrees, recommendations, etc. have been passed which states that at this moment, COVID-19 is still being considered, as a transient problem, where after the end of the pandemic, it would return to the already existing strategies of development and sustainability.

Keywords: sport, pandemic COVID-19, sport future, sustainability, development strategy, recreational sport, top sport, school sport.

\section{UVOD / INTRODUCTION}

Sport, kao antropološko društveno-istorijski fenomen kroz epohe ljudskog društva beležio je značajne elemente koji su u određenim periodima ljudskog društva imali uticaja na njegov kasniji razvoj. Upravo smo svedoci vremena kada pandemija COVID-19 svojim prisustvom utiče na svakodnevni život pojedinca, time i na sport kao aktivnost ili delatnost kojom se ljudi bave. Imajući u vidu da je planeta zatečena pojavom pandemije COVID-19, mnogobrojni su pokušaji (uspešni i neuspešni) u stabilizaciji sporta kao društvene aktivnosti.

Da bi sagledali mogućnosti budućeg razvoja sporta nakon uticaja COVID-19, neophodno je bilo podsetiti se kako je evoluirao kroz istoriju naše civilizacije. $U$ različitim epohama sport je imao različite faze svog razvoja u zavisnosti od objektivnih okolnosti, odnosno društveno-ekonomskog uređenja zajednica toga doba. Možemo reći da je sport u starom veku svoju zlatnu fazu imao u periodu oko $\mathrm{V}$ veka p.n.e. u antičkoj Grčkoj, kada se vežbalo kako zbog „kalokagatije“ (usklađene lepote tela, uma i duha), tako i zbog časti "da se bude prvi među najboljima“, a ne zbog materijalne dobiti (Pausanija, 1994; Ćirić, 1996; Swaddling, 1999; Šiljak, 2007). Već u doba starih Rimljana, sport menja svoj karakter i postaje sa jedne strane zabava za mase, a sa druge začeti su prvi oblici profesionalizma, prvi oblici sponzorstva - gde mecene ulažu u svoje borce da bi pobedili. Takođe, više se ne navija za najboljeg kao antičkoj Grčkoj, već prema partijskoj opredeljenosti - plavi, zeleni, crveni, beli (Šiljak, 2007). Pojava i jačanje hrišćanstva su doveli tokom srednjeg veka do totalne zabrane ne samo u nadmetanjima, već u bilo kakvom bavljenju sportom jer se smatralo jeresi da se posvećuje pažnja svome telu. Kroz neophodne vežbe vitezova radi odbrane svojih poseda i država, fizičke aktivnosti su vremenom polako počele da se vraćaju kroz neku formu sporta. Humanizam i renesansa su doprineli da se ukaže na značaj vežbanja omladine tokom razvoja, da bi tek u XIX veku počele ozbiljnije aktivnosti sporta da primećuju.

Tokom XX veka sport je doživeo veliku ekspanziju kako u masovnosti bavljenja, tako i rezultatski. Prateći činioci sporta poput sportskih organizacija, sportske industrije, menadžmenta, medija, zbog svog uzajamnog delovanja neminovno su doveli do profesionalizacije sporta. Pitanje budućnosti sporta već se postavljalo među naučnim radnicima ali iz sasvim drugog razloga. Naime, istraživanja su ukazala da dostignuti rekordi u određenim sportskim granama predstavljaju skoro maksimalno moguća dostignuća. Razvoj sporta se između ostalog usmerio inoviranjem postojećih i uvođenjem novih sportskih grana. Značajno je napomenuti da savremena nauka, tehnologija i sport su sarađivali tesno u pravcu korišćenja nanomaterijala za sportsku opremu i rekvizite u cilju poboljšanja njihovih performansi i posledično postizanju boljih sportskih dostignuća (Stefanović et al., 2020).

Takođe, savremeni sport svoj dalji razvoj je postepeno usmeravao kroz međusobnu saradnju sa naučnicima i stručnjacima iz polja robotike. Primena robotike se ogleda u pružanju podrške tokom sportskog treninga, zamene ljudi tokom obuke, pomoći organizatorima tokom sportskih događaja, pa i samom takmičenju, međusobnom ili protiv ljudi (Benson et al., 2013; Erdmann, 2013; Veselinović et al., 2020). 
Značajno je napomenuti da je pre jednog veka, odnosno 1918. godine svet bio suočen sa pandemijom „španske groznice“, gde je tokom njenog dvogodišnjeg trajanja bilo zaraženo oko 500 miliona stanovnika, a smrtno stradalo između 50 i 100 miliona (https://nova.rs/sport/ostalo/koronavirus-sport-svetrat-groznica/). O ovoj pandemiji je najviše pisano u Španiji, zbog čega je dobila naziv po njoj. U to vreme medicinske nauke još nisu imale saznanja o virusima kao danas. Ova pandemija je pokazala značaj međunarodne saradnje $u$ borbi protiv nje, jer je Liga naroda, preteča UN, 1923. godine osnovala Zdravstvenu organizaciju, kao tehničku agenciju koja je stvorila nove sisteme međunarodne kontrole epidemija. Naslednik ove organizacije je Svetska zdravstvena organizacija (SZO) koja je formirana 1948. godine.

Grupa američkih ekonomista sa Prinstona analizirala je primenjene kontra-pandemijske mere gde su utvrdilii da su gradovi koji su imali strože mere imali brži ekonomski oporavak. Mere su trajale oko 4 nedelje i zatim popuštale pod pritiskom javnosti, iako je procena da bi broj smrtnih ishoda bio manji da su trajale do 12 nedelja. COVID-19 je podsetio na ovu pandemiju koju je pratila neviđena medijska cenzura (Ashton, 2020). Mnoga sportska prvenstva nisu završena ili su odložena (Brazil, Amerika, Španija i dr.).

U savremenom dobu, sport je zauzeo veoma značajno mesto kao planetarni fenomen. Razmatrajući perspektivu sporta u 21. veku, kada su do sada donete strategije za njegov održivi razvoj blokirane pandemijskom situacijom, nameću se aktivnosti u pravcu sanacije postojećeg stanja i redefinisanja strategija razvoja sporta u smislu njegovog što bržeg "oporavka“.

Kompleksnost sporta između ostalog ogleda se u činjenici da termin obuhvata različite kategorije učesnika i različite nivoe nadmetanja. Skoro svaki istraživač u oblasti sporta je dao svoju definiciju sporta, gde se te definicije uglavnom dopunjuju u bližem objašnjenju termina sport (Kostadinović, 2004; Bratić at al., 2006 i dr.). Veoma kratku i jasnu definiciju sporta dao je Stefanović, gde pod terminom sport podrazumeva „nadmetanje u telesnoj veštini u kojoj dominira takmičarski duh“ (2011). Međutim, neusaglašenost istraživača $u$ oblasti sporta oko njegove sistematizacije dovodi nas do prisustva većeg broja sistematizacija i definicija termina sport. Sistematizacija sporta neophodna je iz više razloga, gde je osnovni razlog lakše izučavanje pojedinih grupacija sportskih oblasti koje imaju neku zajedničku karakteristiku.Podela sporta se može ustanoviti prema različitim kriterijumima: prema broju učesnika, prema prostoru u kome se održava sportska aktivnost, na osnovu strukture takmičarske aktivnosti, prema načinu određivanja sportskog rezultata i dr. Tako na primer postoji podela na olimpijski i neolimpijski sport, vrhunski i masovni, amaterski i profesionalni itd. Da bi se vrhunsko sportsko stvaralaštvo koje je prisutno u profesionalnom sportu iskazalo u svom punom obimu, neophodno je posvetiti pažnju i dečijem/omladinskom sportu u cilju kvalitetnog razvijanja mogućih potencijala vrhunskog sporta. Sve navedene grupe su ugrožene zbog restriktivnih mera u cilju sprečavanja širenja pandemije.

Za masovni sport je karakteristično korišćenje sportskih sredstava (vežbi) u cilju harmonijskog razvoja čoveka, poboljšanja zdravlja i preventive bolesti, samopotvrđivanja i samoprevazilaženja, i racionalne organizacije slobodnog vremena. Rekreacija predstavlja sastavni deo sporta kao društvene delatnosti. Cilj sportske rekreacije jeste da omogući optimalne uslove i mogućnosti savremenom čoveku da kroz raznovrsne sportsko-rekreativne aktivnosti zadovoljava svoju bio-psiho-sociološku potrebu za kretanjem i igrom, sadržajnije i kreativnije provodi slobodno vreme, čuva i unapređuje zdravlje, održava vitalnost, životni i radni optimizam, održava i unapređuje svoje opšte fizičke, funkcionalne i radne sposobnosti, otklanja prevremenu pojavu starenja i produžava aktivni radni vek i kreativnost do duboke starosti. Sportska rekreacija je prevashodno usmerena na zadovoljavanje autentičnih potreba i interesa onih pojedinaca koji svoje potrebe ne zadovoljavaju kroz postojeći sistem školskog fizičkog vaspitanja, a nemaju interesa, talenta, sposobnosti ili nisu motivisani da se bave sportom.

Dosadašnji problem ove vrste masovnog sporta koji se odnosio na nedovoljan broj angažovanja pojedinaca zbog sve veće problematike obezbeđenja egzistencije na štetu slobodnog vremena i bavljenja svojim zdravljem, pojačan je ograničenim vremenskim kretanjem tokom vanrednog stanja koji je $u$ skoro svim državama na našoj planeti bio prisutan, gubitkom radnih mesta i slabljenjem platne sposobnosti, kao i opravdanim strahom velikog broja ljudi od kontakata sa drugima što je dovelo do socijalnog distanciranja, pa čak i psihičih tegoba zbog nastale situacije (Saladino et al., 2020).

Vrhunski sport zastupaju sportisti u pojedinačnim i ekipnim sportovima vrhunskog nivoa, gde se ostvaruju njihovi najveći dometi na olimpijskim, svetskim, kontinentalnim i drugim velikim regionalnim takmičenjima. On pripada onim ostvarenjima gde se ostvaruju maksimalna sportska dostignuća/rekordi. lako je cilj svakog takmičenja u vrhunskom sportu pobeda, odnosno samopotvrđivanje, na sportskim 
borilištima se ne odvija samo borba za medalje. Ulazak profesionalizma i komercijalizacije u sport neminovno je doveo do pratećih pojava koje direktno utiču na sam sport. Jedna od njih je sportski biznis, u kojem su u igri enormne sume novca - od onog, koji daju sponzori sportskih nadmetanja do milionskih svota koje se nude sportistima za prelazak iz jednog tima u drugi ili za pobede na prestižnim takmičenjima (Šiljak, 2007). Olimpijski sport u okviru Olimpijskog pokreta pod rukovodstvom MOK zalaže se kao za vrhunski sport, tako i za masovni sport.

Bavljenje sportom usmereno ka stvaranju novih vrednosti, među koje spada i sportski rezultat, zahteva transdisciplinarni pristup. Nauka iz oblasti sporta upotrebljava postignute sportske rezultate u raznim pravcima. Naučnik iz oblasti sporta, trener i sportista, ako imaju naučno interesovanje, uvek će eksperimentisati sa raznim dostignućima, novim metodama, i verovatno novim aktivnostima. Kroz istraživanja se unapređuje postojeći program trenažnog rada. Visoki sportski rezultati koji se danas postižu, na određeni način govore o tome kolike su granice ljudskih mogućnosti. Međutim, svedoci smo velikog broja odloženih sportskih takmičenja zbog COVID-19, poput Olimpijskih igara Tokio 2020 (IOC, 2020).

\section{MATERIJALI I METODE / \\ MATERIALS AND METHODS}

U savremenim sistemima ništa nije prepušteno slučaju, tako da i u sportskoj rekreaciji postoji sistem rada, tj. strategija razvoja i uključivanja što većeg broja ljudi u razne sportske aktivnosti. Aktivan način života i otklanjanje faktora rizika, u mnogome olakšavaju savremeni život (Šarkej i Gaskili, 2008). Fizička aktivnost ima brojne zdravstvene koristi i efekte kako na odrasle osobe, tako i na mlađu populaciju, odnosno decu (Bauman, 2004). Ova sfera sportskog angažmana postala je životna filozofija doživljavajući naglu socijalnu ekspanziju, a u poslednje vreme postala je i društveni prestiž. Relaksacija od dnevnih obaveza i profesionalnog angažmana je ujedno i priprema za bolje podnošenje predstojećih opterećenja životnog ciklusa. Aktivnosti u okvirima rekreativnog bavljenja sportom (Johanson; Kristi 2005) su po prirodi takve da individualno odgovaraju klijentima (vežbačima).

Od trenutka izbijanja pandemije COVID-19 pa do završetka ovog istraživanja stav svih nacionalnih i globalnih kreatora politika suštinski je menjan $u$ više navrata i često je bio kontradiktoran, što je najverovatnije bilo posledica nepoznavanja problema i njegovih mogućih posledica, odnosno, suočavanja sa novim i nepoznatim. Nedostajao je sistem- ski i sveobuhvatni pristup u sagledavanju problema pandemije, kao i njegovih posledica po zdravlje, bezbednost, ekonomiju, sport i druge segmente savremenog društva, kako na lokalnom i regionalnom, tako i na globalnom nivou. Međutim, iako su se brojni autori bavili problematikom COVID-19 sa aspekta sporta, imajući u vidu činjenicu da je sport kompleksan fenomen, ostavljeno je dosta prostora za dalja istraživanja o njihovoj povezanosti, odnosno uticaju COVID-19 na sport.

Predmet ovog istraživanja se upravo odnosi na uticaj COVID-19 na budućnost sporta, njegovu održivost razvoja, tj. oporavka. Cilj istraživanja predstavlja sveobuhvatno sagledavanje i razumevanje problema i dimenzija aktuelne pandemije COVID19 u funkciji održivog razvoja sporta. Polazeći od predmeta i cilja istraživanja definisana su sledeća istraživačka pitanja:

1. Koja je realna perspektiva masovnog sporta (školskog i rekreativnog)?

2. Koja je perspektiva vrhunskog sporta?

3. Da li je neophodno postojeće strategije razvoja sporta redefinisati?

Kompleksnost sporta se može pratiti kroz navedena pitanja koja nisu sama po sebi izdvojena, već obuhvataju polje edukacije (školski sport), sportskog turizma (rekreativni i vrhunski sport), zdravstveni aspekt (svi akteri) i dr.

Uticaj bavljenja sportom (rekreativnim i vrhunskim) na otvorenom prostoru na naše prirodno okruženje je veliki. Istraživači su identifikovali četiri ključne oblasti. Ova područja uključuju srž teme procene uticaja na životnu sredinu sporta i rekreacije na otvorenom, ponašanja i odlučivanja pojedinačnih i kolektivnih aktera, uticaja upravljanja na održivost životne sredine i budućih okvirnih uslova. Procena uticaja sporta i rekreacije na životnu sredinu je osnova za razumevanje kako pravilno rešiti ekološku održivost u navedenim oblastima u budućnosti. Istraživači i praktičari treba da budu svesni da programi zaštite životne sredine nisu podložni izomorfnoj institucionalizaciji, što može dovesti do neefikasnih inicijativa za postizanje određenih organizacionih ciljeva održivosti životne sredine, kao i da moraju poznavati razliku između sektora - sport za gledaoce, sport za učešće i rekreacija na otvorenom (McCullough, 2018).

$\mathrm{U}$ ovom istraživanju eksplorativnog karaktera, $\mathrm{s}$ obzirom da se odvija u uslovima aktuelne pandemije, u realnom vremenu, primenjena je deskriptivna, pretežno kvalitativna i kritička analiza sadržaja javno dostupnih, zvaničnih i objavljenih podataka i naučnih radova, kao i publikacije statističkih institucija kojima se na jasan, naučan i nedvosmilen 
način mogao ostvariti formulisani cilj istraživanja. Aktuelnost teme je neupitna i diktira je stvarnost $u$ kojoj živimo.

\section{REZULTATI I DISKUSIJA / RESULTS AND DISCUSSION}

Udruženje za medicinu sporta Srbije zajedno sa udruženjem kardiologa je u decembru prošle godine dalo kliničke preporuke za povratak sportu tokom COVID-19 pandemije (UMSS, 2020). Preporuke se odnose podjednako i na vrhunske i na rekreativne sportiste. Pored preporuka je ostavljena mogućnost kontakta zainteresovanih radi dobijanja stručnog saveta. Značajno je napomenuti da u Preporuci ukazuju, da povratak sportskim aktivnostima mora da se odredi individualno za svakog sportistu u odnosu na klinički tok COVID-19, gde je obavezno razmotriti prethodno zdravstveno stanje sportiste, sportsku granu i dsciplinu kojom se bavi. Analizom rezultata istraživanja može se zaključiti da je perspektiva školskog i vrhunskog sporta i uz napore resornih udruženja na zabrinjavajućem nivou, dok je segment rekreativnog sporta moguće održati na istom nivou uz preorijentaciju i usmerenost na bavljenje aktivnostima na otvorenom prostoru.

Posledice pandemije na fizičko i mentalno zdravlje društva moći će objektivno da budu istražene nakon određenog vremenskog protoka, međutim, iako veliki broj istraživača svojim radovima pokušava da ukaže na slabosti i probleme s kojima je društvo suočeno, prisutna su neslaganja oko porekla i načina reagovanja na suočavanje sa izazovom prisustva COVID-19. lako je pandemija globalnog karaktera, države samostalno donose propise o merama zaštite, bezbednosti i funkcionisanja medicinskog i svih drugih sektora u svojoj zemlji, tako da imamo razlike u njihovoj primeni.

Centar za sport i ljudska prava, mlada svetska organizacija formirana 2018. godine u Ženevi, veoma je brzo reagovala na pojavu COVID-19 tako što je objavila u junu 2020. godine Pregled uticaja COVID-19 na decu koja se bave sportom. Naime, grupa od 37 stručnjaka zabrinuta za decu koja se bave sportom, bilo profesionalno, bilo u okviru školskog tima, zbog trenutne pandemijske situacije pokušala je razmenom informacija, dobrih primera iz prakse, raspravom o konceptima i na kraju objavljivanjem svojih rezultata rada da pomogne svojim saznanjima svima koji su uključeni u procesu bavljenja dece sportom (Burrows et. all, 2020). Rezultati istraživanja ovog brojnog tima stručnjaka ukazuju da je pandemija COVID-19 imala značajan uticaj na život dece širom sveta u različitim domenima. Pozivajući se na dokumenta UN autori ističu da je početkom pandemije 188 zemalja zatvorilo svoje škole kao odgovor na njenu pojavu, za šta su procenili da je dovelo do toga da je preko 1,5 milijardi dece značajno izgubilo vreme za obrazovanje. Dalje, procenili su da će dodatnih 42-66 miliona dece biti u krajnjem siromaštvu kao rezultat pandemije. Posledično je logično zaključiti da su ima smanjene mogućnosti bavljenja sportom. Želja ovih stručnjaka iz oblasti prava deteta, zaštite i zaštite u sportu bila je da njihova zapažanja budu vidljiva donosiocima odluka, od sportskih organizacija, lokalne i državne samouprave, do kompetentnih međunarodnih zajednica. Razmatrane su četiri oblasti: sport u toku, odsustvo sporta, deca u osetljivim i posebnim situacijama i budući uticaji i brige. Mišljenja su da bi bilo neophodno vršiti dalja istraživanja na aktuelnu temu i da je imperativ čuti glas dece, odnosno njihovo mišljenje da bi se validno postavili prioriteti, uspostavila pravila i procedure za prilagođavanje ovoj novoj stvarnosti. Značajno je da informacije i obrazovanje o COVID-19 i svim povezanim rizicima budu prilagođene i pristupačne deci sportistima, bez izuzetka (Burrows et. all, 2020).

Svoj stav o nošenju zaštitnih maski tokom bavljenja sportom dece školskog uzrasta izneo je bivši američki sportista koji se u više sportskih grana takmičio za svoj koledž. Kako je na Prinston univerzitetu (Princeton University) stekao obrazovanje u oblasti molekularne biologije i virologije, a trenutno radi kao ortopedski hirurg sportske medicine, izuzetno je značajno njegovo mišljenje i stav, imajući u vidu njegovu direktnu povezanost sa sportom i medicinom. Danas smo na žalost svedoci velikog broja različitih informacija koje nam stižu od medicinskih radnika koje često mogu biti i oprečne. Pojedinac je prepušten sebi da prepozna pravu informaciju o merama za zaštitu zbog COVID-19, a kod dece koja se bave sportom su to roditelji i treneri, ali najpre stručnjaci poput Artura koji povezuju obe oblasti.

Nakon donošenja novih mera u Minesoti u januaru 2021. godine, koje se tiču nošenja zaštitnih maski kod srednjoškolskih sportista, Artur je ukazao na niz nelogičnosti u toj uredbi. Prema toj uredbi svi sportisti moraju da nose maske osim rvača, plivača, gimnastičara i navijačica. Osim toga što smatra nelogičnim da rvači, koji su u direktnom kontaktu, ne nose maske, Artur je ukazao na mogućnost velikog broja povreda zbog suženog vidnog polja sportista, kao i do drugih infekcija nastalih nošenjem maski tokom utakmica zbog znojenja ili drugih lučenja sekreta sportista (Arthur, 2021). Smatra da je bolje odložiti sportske događaje nego da se sprovode po navedenim uslovima. S druge strane Asocijacija američkih pedijatara insistira da 
deca nose zaštitne maske tokom bavljenja sportskim aktivnostima (H. Children, 2021).

Školski i univerzitetski sport u svetu funkcionišu u skladu sa svojim nazivom i podrazumevaju međusobna takmičenja i lige na nivou uzrasta sportista. U Republici Srbiji, iako su školski i univerzitetski sport zakonom definisane kategorije, realnost je potpuno drugačija što je svakako tema kako za neka druga istraživanja, tako i za nadležne organe i institucije u oblasti sporta. Deca školskog uzrasta uključena su u sport ili kroz klubove (privatne, državne) i školska takmičenja se odvijaju tako što ekipu škole predstavlja ekipa ili pojedinac koji se bavi tim sportom $u$ nekom klubu nezavisno od škole koju pohađa, uz uslov da mu klub dozvoli. Iz navedenog razloga, tema rada je preusmerena na realnu aktivnost dece na časovima fizičkog vaspitanja pod uticajem COVID-19 u Srbiji. Ministarstvo prosvete RS pripremilo je u avgustu prošle godine plan nastave u osnovnim i srednjim školama (IngPro, 2020). Prema ovom planu, zajednička stavka je skraćivaje trajanja školskog časa na 30 minuta. Data su dva modela koja se dalje adaptiraju u svakoj školi u zavisnosti od mnogih pratećih činilaca. U isto vreme se oglasio predsednik Srpskog saveza profesora fizičkog vaspitanja i sporta, Miroslav Marković, koji je izneo zanimljive podatke ankete sprovedene među nastavnicima fizičkog vaspitanja o načinu držanja nastave u uslovima pandemije (Andrić, 2020). Rezultati sprovedene ankete pokazuju da $47 \%$ smatra da nastava ovog predmeta treba da se izvodi isključivo u školi poštujući mere bezbednosti, dok oko 33\% anketiranih je za kombinovanu nastavu - smenjivanje časova u školama i onlajn nastave. Ipak, generalni stav udruženja nastavnika ima stav da nastava fizičkog vaspitanja treba da se izvodi u školi u skladu sa preporukama, da bi omogućili deci konkretnu, usmerenu, vođenu fizičku aktivnost koja im je neophodna kao preventivna mera u očuvanju zdravlja (Andrić, 2020).

Međutim, ako smo formalno pokrili polje bavljenja fizičkom aktivnošću dece u školi, a praksa pokazuje drugu sliku, postavlja se pitanje odgovornosti. U praksi, deca se opredeljuju da li da idu u školu ili će je pohađati samo online putem. Od one dece koja su se opredelila da idu u školu i podeljena su po odeljenjima $u$ dve grupe, realno je da imaju nedeljno održan samo jedan čas fizičkog vaspitanja od 30 minuta, dok se drugi čas održava online putem (teoretski deo). Zatim, u nekim školama se časovi fizičkog održavaju samo napolju jer su sale pretvorene u dnevni boravak dece zbog propisanih mera držanja distance i broja đaka u datom prostoru. Svedoci smo i TV časova fizičkog vaspitanja koji su najviše bili aktuelni tokom van- rednog stanja, gde su takvi časovi mogli imati pozitivan efekat više na psihičko nego na fizičko zdravlje deteta.

Povećan broj zaraženih sa COVID-19 je bio očekivan imajući u vidu informacije ljudi koji su se vraćali sa zimovanja. Od subjektivnih, ali ne i netačnih iskaza pojedinaca, do fotografskih prikaza situacija gde je zabeleženo nepoštovanje mera i držanja distance u redovima na žičarama, dovelo je do objektivnih problema povećanja obolelih (Marković, 2021). Zatim, međudržavni različiti propisi i administrativni zahtevi su u pojedinim slučajevima dovođeni do apsurda, tako da je pod sintagmom „poštovanja propisa“ grupa ljudi koja se vraćala iz Bosne i Hercegovine sa zimovanja, stavljena u izolaciju zbog prolaska kroz Hrvatsku (Bulajić, 2021).

Evidentno je da je organizacija sportskih događaja zbog uticaja COVID-19 mnogo zahtevnija i komplikovanija. Neki sportski događaji su, poput Olimpijskih igara u Tokiju, odloženi, neki ne dozvoljavaju prisustvo publike, dok su neki sportski događaji poput teniskog GS turnira Australien Open imali publiku.

Sportski događaji nas vraćaju na njihove glavne aktere, odnosno vrhunske sportiste i probleme sa kojima se susreću pod uticajem COVID-19. Početkom pandemije, kada je došlo do tzv. „zatvaranja" država, otkazivanja takmičenja, uvođenja policijskog časa, najviše se govorilo i pisalo o mentalnoj stabilnosti sportista ali i svih ostalih ljudi. Međutim, protok vremena je iznedrio probleme koji nisu uočeni na samom početku epidemije, a trebalo ih je predvideti ako se poznaje problematika trenažnog procesa, odnosno odvijanja fizioloških procesa tokom fizičkog napora sportista. Odgovorno tvrdeći da u stručnom nadmetanju medicinske struke, gde je očigledno važnije da se ima bilo kakvo preporuka, da li zbog lične afirmacije ili političko-ekonomskih razloga, zaboravilo se na osnovni postulat, da su prave preporuke samo one koje su ispravno zasnovane i utemeljene na činjenicama. Mali broj sportista će čitati naučne članke ako prethodno veliki broj pisanih i štampanih medija prenosi informaciju "zdravstvene struke" koje su oprečne, poput nošenja zaštitne maske tokom treninga i dr. Broj smrtnih ishoda među sportistima i sportskim radnicima nije zanemarljiv. Postoji spisak sportskih zvezda koje su preminule usled COVID-19 (Outlook, 2020).

Pored komplikacija koje izaziva na respiratornom sistemu, virus COVID-19 naročito ugrožava srce i kardiovaskularni sistem. Poremećaji srca, uključujući miokarditis, pokazali su se kod velikog broja pacijenata hospitalizovanih zbog COVID-19 (Knight, 2021). Kod sportista je to izraženije iz razloga što čim nemaju temperaturu i negativan im 
je PCR test, vraćaju se treninzima za koje nisu fizički spremni, ali objektivno nisu toga svesni. Veliki broj njih nije imao klasične simptome bolesti, poput naše teniserke Dejane Radanović, koja je zbog osećaja umora uradila PCR test gde je rezultat bio negativan. Nastavak trenažnog procesa, i dalja prisutnost povećanog umora su je naveli da se obrati kardiologu. $\mathrm{Na}$ žalost, rezultati pregleda su pokazali lošu kliničku sliku i prema njenim rečima, ni nakon četiri meseca od tada nije došlo do kompletnog poboljšanja (Ljubisavljević, 2021).

Vakcinisanje u svrhu zaštite od COVID-19 donosi određene zahteve koji se moraju poštovati. Među njima je preporuka profesora Tiodorovića, člana kriznog štaba RS, da se nakon primanja vakcine do nedelju dana ne sme baviti težim fizičkim aktivnostima, poput odlaska u teretanu (Spasić, 2021). Poznavanje problematike sporta, naročito vrhunskog, način razmišljanja samih sportista i trenera, na šta su sve spremni da bi postigli vrhunski rezultat bila je tema velikog broja istraživača čiji rezultati istraživanja pokazuju da ne ide u prilog racionalnom razmišljanju i očuvanju ličnog zdravlja. Ako se ne ceni lično zdravlje, kako se može očekivati poštovanje tuđeg zdravlja. Upravo iz tog razloga je neophodno dodatno se baviti preventivom i kontrolom zdravstvenog stanja vrhunskih sportista tokom trajanja epidemije.

U prilog brizi o zdravlju sportista ide činjenica da je Međunarodni olimpijski komitet nakon pojave COVID-19 udružio svoje snage sa Svetskom zdravstvenom organizacijom kao i sa Ujedinjenim nacijama (WHO, 2020). Cilj ovog partnerstva je da olimpijski sportisti ukažu na globalnu saradnju potrebnu za očuvanje zdravlja i smanjenje širenja i uticaja COVID-19. Takođe, MOK je osnovao tzv. „Medicinsku COVID-19 bazu“ (IOC Medical COVID-19 Hub), čiji cilj je da pomogne pomoćnom osoblju u pružanju dobre medicinske nege olimpijskim sportistima. MOK je okupio međunarodnu grupu stručnjaka za respiratorne bolesti kako bi razvili konsenzusnu izjavu o akutnim respiratornim bolestima kod sportista. Ova organizacija shvata izazove pronalaženja, proučavanja i delovanja na protok trenutnih informacija. Ova baza će pomoći svima koji su uključeni u negu sportista da odluče da li su vesti stvarne ili lažne i da li se navodni naučni proboj zasniva na stvarnim podacima ili je hipotetička ekstrapolacija (IOC, 2021).

Nakon izloženih činjenica, ne možemo da se ne upitamo gde je budućnost sporta? Da li će biti „bolja“ ili „lošija“? Dokle će biti prisutan virus? Na neka pitanja, poput poslednjeg, ni nauka ne može da odgovori. Profesor Koković, poznati sociolog u oblasti sporta smatra da sport kakav danas znamo, nećemo više gledati u budućnosti. Navodi da zbog ekonomskih posledica COVID-19, egzistencija ljudi je došla u krizu i posledično je došlo i do opadanja zainteresovanosti za praćenje sporta. Ovu tvrdnju je potkrepio informacijom o smanjenoj gledanosti završnice NBA turnira prošle godine u Orlandu za 51\% (Živanović, 2020). Takođe, ukazuje na mogućnost da mnoga „ad hoc“ rešenja postanu trajna, kao i da se još uvek traže pravi modeli rešenja za prevazilaženje problema u svim segmentima sporta.

\section{ZAKLJUČAK / CONCLUSION}

Uticaj globalizacije na sport se do sada ogledao u pojavi globalne konkurentnosti, koja je u sportu stalno prisutna. Veliki sportski klubovi prerasli su u multinacionalne kompanije pa se danas imena tih velikih kompanija više ne mogu vezivati samo za pojedinačne zemlje i nacije već su njihova obeležja mnogo šireg, međunarodnog karaktera. Globalizacija je zbog visoke međuzavisnosti privrednih sistema, organizovanja proizvodnje u transnacionalnom obliku i sve većeg uticaja međunarodnih organizacija (MMF-a, Svetske Banke, WTO i sl.) bitno uticala na smanjenje nezavisnosti velikih regija pa i čitavih država. To se odrazilo i na sport i sportska dešavanja, jer su pravila koja su utvrđena od strane međunarodnih sportskih federacija ili pojedinih asocijacija klubova toliko obavezujuća za sve sportske aktere da naprosto imaju veću snagu od samih nacionalnih zakona u okviru kojih te članice funkcionišu. To je i sasvim logično ako se ima u vidu činjenica da vrhunski sport sam za sebe ne može ni postojati u okviru samo jedne države ili teritorije, jer on epitet vrhunskog sporta dobija upravo kroz valorizaciju rezultata na međunarodnom planu i u međunarodnim okvirima.

Pored toga, globalizacija je doprinela razvijanju tržišno-ekonomske pozicije sporta, njegovog društvenog delovanja u svim glavnim pravcima društvenoekonomske i društveno-političke strukture, što ukazuje da on zauzima sve širi i sve značajniji društveni prostor i da stiče vrlo značajnu društvenu poziciju. $U$ protekle tri decenije, kao rezultat komercijalizacije, sport koji je imao dugačku nekomercijalnu istoriju, prešao je put od igre (razonode) do ozbiljnog biznisa. Oko toga da li komercijalizacija više pomaže ili odmaže sportu mišljenja su podeljena. Smatra se da je do naglog širenja komercijalizacije u sportu najviše doprinela interakcija sledecih faktora: težnja ka sportskom spektaklu, razvoj tehnologija, povećanje konkurencije, glad za rekordima i profesionalizacija menadžmenta (rukovodstva) u sportu.

Do danas se sportski menadžment razvio u posebnu industrijsku granu koja donosi velike profite sportskim organizacijama. Poslovanje u uslovima 
globalizacije radikalno menja tržište, uslove i snagu konkurencije, zahtevajući od menadžera promene u načinu reagovanja i rešavanju problema. Najuspešnije sportske organizacije postaju one koje kontinuirano podstiču kreativnost i kreiraju novo znanje. Upravljanje znanjem predstavlja strategijsku primenu kolektivnog znanja organizacije u cilju povećanja tržišnog učešća, pobeđivanja konkurencije, stvaranja profita, jednom rečju obezbeđenja dugoročnog rasta i razvoja organizacije. Danas organizacije sve više upošljavaju i primenjuju znanje. One obrađuju informacije, definišu planove i strategije, odlučuju, prate ponašanje $i$ iskustva $i$ na osnovu toga stvaraju i uče. Specifičnosti sporta i sportske industrije uopšte i njihov razvoj uslovili su da nekada u sportu dolazi do preplitanja funkcija menadžera i lidera. Menadžment podrazumeva upravljanje materijalnim resursima dok se liderstvo fokusira samo na ljudske resurse. Liderstvo ima posebno mesto u transformaciji organizacija koje su prihvatile koncept kvaliteta. Opstanak i razvoj savremenih sportskih organizacija zavisi od uspešnosti rukovodstva da se suoči sa izazovima turbulentnog okruženja u kome je prisutan visok rizik i neizvesnost. Uloga lidera je od posebnog značaja u procesu dizajniranja nove organizacione strukture,i može doprineti bržem i boljem razvoju i radu sportskih organizacija. Upravo se od segmenta menadžmenta u sportu očekuju novi strateški pravci kojima bi se sanirali i prevazišli postojeći zastoji u sportu nastali pod uticajem COVID-19.

Ako znamo da je sportski turizam tržište koje objedinjuje ljubitelje sportskih događaja, ali i one koji se pojedinačno i grupno ili rekreativno bave sportom pretpostavka je da će se turizam orijentacijom na posebnim i pojedinačnim bavljenjima sportom imati mogućnost za održive i stabilne prihode. Istraživačka i savetodavna kompanija Tehnavio (Technavio) koja se bavi proučavanjem tržišta, napravila je plan oporavka tržišta sportskog turizma, gde je između ostalog predloženo povećanje broja sedišta u arenama gde se odvijaju sportska nadmetanja, radi držanja propisane distance (Technavio, 2020).

Kompleksnost teme je očita, kako zbog međusobne povezanosti rekreativnog sporta i turizma, tako i zbog povećane fizičke aktivnosti na otvorenom, odnosno povećanog broja ljudi, koji su se zbog nametnutih restriktivnih mera zbog pandemije okrenuli prirodi. To nas dodatno zabrinjava, s obzirom da je od ranije uočen problem ekološke odgovornosti turizma.Posledice pandemije na sport, odnosno, fizičko i mentalno zdravlje svih sportista i sportskih radnika i društva u celini, neslaganja oko porekla i načina reagovanja uz druge prisutne izazove i bezbednosne kontradikcije sa kojim se savremeni sport suočava mogu biti pokazatelji koji ukazuju na trajne promene odnosa među ključnim akterima na svetskoj sportskoj sceni. Efekti infodemije koja od samog početka prati pandemiju COVID-19 i oblikuje stavove pojedinaca, ali i šire društvene, a i sportske procese, mogu značajno uticati na zdravlje sportista.

Među preporukama nastavnika fizičkog vaspitanja i sporta je ta da akcenat treba da bude na bezbednim i zabavnim aktivnostima napolju, koje promovišu celoživotni fitnes, relaksaciju od stresa i zdravu ishranu, što nas dovodi do pitanja bavljenja rekreacijom drugih uzrasnih kategorija. Prethodna tvrdnja navodi na logičan zaključak da su u većini slučajeva, sa izuzetkom teretana, rekreativne aktivnosti redukovane $u$ zatvorenim prostorima i da su se ljudi okrenuli ka onim aktivnostima koje mogu da upražnjavaju na otvorenom prostoru. Zimski sportski turizam 2020/21 zbog široke lepeze sportskih aktivnosti koje mogu da se upražnjavaju na otvorenom prostoru, kao i zbog ekonomskog momenta očuvanja turizma kao privredne grane je doneo je i prateće probleme. Za sada nije uočeno da su strategije razvoja sporta redefinisane, već je donešen određen broj uredbi, preporuka i sl. što navodi da se u ovom momentu još uvek razmišlja o COVID-19, kao prolaznom problemu, gde bi se nakon završetka pandemije vratilo već postojećim strategijama razvoja i održivosti sporta. Međutim, pandemija COVID-19 pokazuje neophodnost potpuno novog globalnog i nacionalnih pristupa u cilju jačanja kapaciteta za odgovor na krizne situacije u sportu. Neophodno je sveukupno jačanje resursa (obrazovanja, medicine, nauke u domenu sporta), odnosno, neophodno je tzv. epidemiološko modelovanje sporta u cilju očuvanja zdravlja sportista i budućnosti samog sporta.

\section{LITERATURA / REFERENCES}

[1] Andrić, V. (2020). Kako organizovati časove fizičkog u trenutnoj epidemiološkoj situaciji. Danas online od 14.08.2020. Dostupno na https://www.danas.rs/drustvo/kakoorganizovati-casove-fizickog-u-trenutnojepidemioloskoj-situaciji/.

[2] Arthur, E. F. (2021). COVID masks for yooung athletes are worse then useless. Startribune online, January 5, 2021. Available at https://www.startribune.com/covid-masks-foryoung-athletes-are-worse-thanuseless $/ 600007113 /$ ?refresh=true.

[3] Ashton, J. (2020). COVID-19 and the 'Spanish' flu. Journal of the Royal Society of Medicine, 113 (5), 197-198.

[4] Bauman, A.E. (2004). Updating the evidence that physical activity is good for health: an epidemiological review 2000-2003. Journal of Science and Medicine in Sport, 7(1), 6-19. 
[5] Benson, B., Semray, J., Debert, C., Scott, S., Meeuwisse, W., Dukelow, S. (2013). Quantitative assessment of sensorimotor dysfunction and recovery using robotics in athletes sustaining an acute sport-related concussion. British Journal of Sports Medicine, 47(5), e 1.

[6] Bratić, M., Kostić, R., Vukajlović, V. (2006). Teorija sporta. Niš: SIA.

[7] Bulajić, J. (2021). Vakcinisan u Srbiji, traže mu PCR posle skijanja u Bosni. Nova portal online, 18/02/21. Dostupno na https://nova.rs/vesti/drustvo/luda-kuca-ivanulalicu-traze-pcr-posle-skijanja-u-bosni/.

[8] Burrows et. all, (2020). An Overview of SportRelated Impacts of the COVID-19 Pandemic on Children. Geneva: Centre for Sport and Human Rights. Available at https://www.sporthumanrights.org/en.

[9] Ćirić, A. (1996). Igre u Olimpiji, Vreme knjige, Beograd.

[10] Erdmann, W. S. (2013). Problems of Sport Biomechanics and Robotics, International Journal of Advanced Robotic Systems, Vol. 10, 123.

[11] Healthy Children, (2021). Masks and Sports: Should Youth Athletes Wear Face Coverings During COVID-19? Available at https://www.healthychildren.org/English/health -issues/conditions/COVID-19/Pages/WhyCloth-Face-Coverings-are-Needed-in-YouthSports-During-COVID-19.aspx.

[12] IOC (2021). IOC Medical COVID-19 Hub. Available at https://www.olympic.org/ athlete365/ioc-medical-covid-19-hub/.

[13] Ing-Pro (2020). Ministarstvo prosvete pripremilo je plan nastave u osnovnim $i$ srednjim školama. Dostupno na https://www.propisi.net/ministarstvo-prosvetepripremilo-je-plan-nastave-u-osnovnim-isrednjim-skolama/.

[14] International Olympic Committee (2020). IOC and Tokyo 2020 Joint Statement - Framework for Preparation of the Olympic and Paralympic Games Tokyo 2020 Folowing Their Postponement to 2021. Available at https://www.olympic.org/news/ioc-and-tokyo2020-joint-statement-framework-forpreparation-of-the-olympic-and-paralympicgames-tokyo-2020-following-theirpostponement-to-2021.

[15] Johanson, J., Christie, J., Wardle, F. (2005). Play, development and early education. Pearson.

[16] Knight, C. (2021). Long-term Effects of COVID19 in Athletes. News Medical Life Sciences online, February 2, 20221. Available at https://www.news-medical.net/health/Longterm-Effects-of-COVID-19-in-Athletes.aspx.

[17] Kostadinović, S. (2004). Pravo i sport. Beograd: Univerzitet „Braća Karić“ Fakultet za menadžment u sportu.

[18] Ljubisavljević, M. (2021). Dejanina borba sa virusom: Narušeno zdravlje, bar sam živa. Nova portal online od 04/03/21. Dostupno na https://nova.rs/sport/tenis/ispovest-srpsketeniserke-unistila-sam-srce-bar-sam-ziva/.

[19] Ljubojević, M. (2020). Da li je gore sada ili pre 102 godine? Kako su izgledale utakmice u vreme španske groznice?. Telegraf online 18/10/20. Dostupno na https://www.telegraf.rs/ zanimljivosti/zabavnik/3249843-da-li-je-goresada-ili-pre-102-godine-kako-su-izgledaleutakmice-u-vreme-spanske-groznice.

[20] Matić, Đ. (2020). Neprijatelji sporta: Ratovi i bolesti koji nisu zaustavili loptu. Nova portal online, 19/03/20/, dostupno na https://nova.rs/sport/ostalo/koronavirus-sportsvet-rat-groznica/.

[21] Marković, M. (2021). Prekinula skijanje zbog nepoštovanja mera, novac nije vraćen. Nova portal online, 03/02/21. Dostupno na https://nova.rs/vesti/drustvo/prekinula-skijanjezbog-nepostovanja-mera-novac-nije-vracen/.

[22] McCullough, B., Bergsgard, N. A., Collins, A., Muhar, A. (2018). The Impact of Sport and Outdoor Recreation (Friluftsliv) on the Natural Environment, Background paper. Available at https://www.researchgate.net/publication/3267 18917_The_Impact_of_Sport_and_Outdoor_ Recreation_Friluftsliv_on_the_Natural_Enviro nment_-Background_paper/citation/download.

[23] Outlook (2020). Here is the List of Sports Stars and Personalities who Died of COVID-19. Available at

https://www.outlookindia.com/website/story/sp orts-news-covid-19-complete-list-of-sportsdeaths-due-to-coronavirus-pandemic/349879.

[24] Pausanija, (1994). Opis Helade, Matica srpska, Novi Sad.

[25] Saladino, V., Algeri, D., Auriemma, V. (2020). The Psychological and Social Impact of Covid-19: New Perspectives of Well-Being. Front. Psychol. 11:577684. doi: 10.3389/fpsyg. 2020.577684

[26] Sharkey, B.J., Gaskili, S.E. (2008). Вежбање и здравље. Београд: Дата Статус.

[27] Stefanović, Đ. (2011). Filosofija, nauka, teorija i praksa sporta. Beograd: Fakultet sporta i fizičkog vaspitanja u Beogradu i autor. 
[28] Spasić, J. (2021). Seks, da, teretana ne! Vodič posle vakcine: Svaki fizički napor je provokacija, čašica alkohola sme, ali ne da vas nose iz kafane!. Kurir online 26/01/21. Dostupno na https://www.kurir.rs/vesti/drustvo/3612077/sek s-da-teretana-ne-vodic-posle-vakcine-svakifizicki-napor-je-provokacija-casica-alkoholasme-ali-ne-da-vas-nose-iz-kafane.

[29] Stefanović, Ž., Šiljak, V., Perović A., Đurović, D., Isaković, M., Vajić, S. (2020). Nanotehnologija u sportu, Ecologica, 27 (98), 281-287.

[30] Swaddling, J. (1999). The Ancient Olympic Games (second edition). British Museum Press, London.

[31] Šiljak, V. (2007). Istorija sporta. Beograd: Fakultet za menadžment u spotru.

[32] Technavio (2020). Sports Tourism Market Post Pandemic Recovery Plan - Strategies and Processes. Increasing Number of Sporting Events to Boost Market Growth. Technavio. Available at https://www.businesswire.com/news/home/20 200914005307/en/Sports-Tourism-Market--Post-Pandemic-Recovery-Plan---Strategiesand-Processes-Increasing-Number-of-
Sporting-Events-to-Boost-Market-GrowthTechnavio.

[33] Tokyo 2020 (n.d.). Tokyo 2020 Games Innovative Initiatives, retrieved on May 23, 2020. from https://tokyo2020.org/en/games/visioninnovati on/

[34] UMSS (2020). Kliničke preporuke za povratak sportu tokom COVID-19 pandemije. Dostupno na http://www.smas.org/novosti.html.

[35] Veselinović, J., Šiljak, V., Perović, A., Mrdak, G., Đurović, D., Nikolić, M. Antonijević, S. (2020). Primena robotike u sportu, Ecologica, 27 (99), 537-543.

[36] WHO (2020). IOC joins forces with WHO and the United Nations to fight COVID-19. https://www.who.int/news/item/23-06-2020ioc-joins-forces-with-who-and-the-unitednations-to-fight-covid-19.

[37] Živanović, V. (2020). Od korona virusa „umire“ i sport. Intervju s profesorom Draganom Kokovićem objavljen u Danas online od 21.11.2020. Dostupno na https://www.danas.rs/sport/odkorona-virusa-umire-i-sport/. 